\title{
Beneficial effect of spider presence on seedling recruitment of the tropical rainforest tree Dipteryx oleifera (Fabaceae)
}

\author{
Javier Ruiz ${ }^{1,2}$, Cherryl Ingram-Flóres ${ }^{2}$, Douglas H. Boucher ${ }^{3}$ \& Luis F. Chaves ${ }^{1}$ \\ 1. Department of Ecology and Evolutionary Biology, University of Michigan, Ann Arbor, MI 48109, USA; \\ jeruiz@umich.edu; lchaves@umich.edu \\ 2. Programa Científico Complementario. Barrio Punta Fría, Frente a Imprenta La Salle Costeña, Bluefields, Nicaragua; \\ cheinflor@hotmail.com \\ 3. Union of Concerned Scientists, 1825 K Street, NW, Suite 800 Washington, DC 20006-1232, USA; \\ dboucher@ucsusa.org
}

Received 18-I-2008. Corrected 22-II-2009. Accepted 25-III-2009.

\begin{abstract}
This research presents evidence showing that: (1) lower arthropod herbivory correlates with seedling survival, and (2) spider presence correlates with lower arthropod herbivory, seedling growth, and seedling survival of the tropical rainforest tree species Dipteryx oleifera in eastern Nicaragua. The study was conducted from January 2005 to January 2006 in a 6.37 ha permanent plot established in 2002. Seedling height, spider behavior and presence on seedlings, and percentage of leaf area lost due to arthropod herbivory were measured. Arthropod herbivory was assessed from digital photographs of each seedling within the permanent plot. Seedling fate was followed in order to determine its correlation with spider presence, initial seedling size, and arthropod herbivory. A GLM showed that seedling survival correlated negatively with lower levels of arthropod herbivory $(<20 \%)$, while seedlings with higher levels of herbivore damage experienced mortalities close to $100 \%$. Results from another GLM suggests that seedling mean height (aprox. $8 \mathrm{~cm}$ ) would be increased by approximately $1.5 \mathrm{~cm}$ for each year that spiders were present on seedlings and would be decreased $0.75 \mathrm{~cm}$ in height for each percent unit of arthropod herbivory. We also report a trend toward lower arthropod herbivory in seedlings colonized by spiders with aggressive traits, presumably because more aggressive spiders better defended seedlings against herbivorous arthropods than less aggressive spiders. Rev. Biol. Trop. 57 (3): 837-846. Epub 2009 September 30.
\end{abstract}

Key words: Dipteryx oleifera, arthropod herbivory, seedling demography, Nicaragua.

Species in a community are thought to be linked directly or indirectly via interactions between consumers and producers e.g. a lake community (Carpenter et al. 2001). In a system with three trophic levels, such as plants, herbivorous arthropods, and predators, a trophic cascade describes the effect of predators on the abundance, richness or structure of the producer's level (Hairston et al. 1960, Levins 1974, Gruner 2004, Moreau et al. 2006). For instance, spiders could lower insect herbivory damages on seedlings and thus could increase plant reproduction (Romero \& VasconcellosNeto 2004). Those upper trophic level effects on plant demography are frequently associated with reduced arthropod abundance (Van Bael et al. 2003, Romero \& Vasconcellos-Neto 2004, Van Bael \& Brawn 2005) or reduced arthropod herbivory (Clark \& Clark 1985).

Foliar herbivory damage can negatively affect seedling (Coley 1983, Dirzo 1987, Coley 1990), and can be severe enough to determine seedling fate (Sullivan 2003). Foliar insect herbivory accounts for about $10 \%$ of the leaf damage in tropical tree species (Dirzo 1987) and the majority of herbivory is by Lepidopteran larvae (Dirzo 1987, Coley 1990, Coley \& Barone 1996). A reduction in arthropod herbivory can lead to higher recruitment rates in tropical rainforest tree species 
(Coley 1983, Coley et al. 1985, Coley 1990, Clark et al. 1993).

Lower seedling recruitment in tropical rainforests may be at least in part determined by herbivorous arthropods effects on seedling fate (Augspurger 1983, Augspurger 1984, Clark \& Clark 1984, Augspurger \& Kitajima 1992, Hyatt et al. 2003). For instance, seedling recruitment of Dipteryx oleifera is negatively correlated with levels of insect herbivory damage. Even when this type of damage was $<8 \%$ of seedling leaf area, this stress seems to have determined seedling survival rates (Clark \& Clark 1985). Since low levels of insect herbivory are omnipresent at the forest floor, more research is needed in order to determine which factor is responsible for seedling transition to larger size stages (Clark \& Clark 1985, Ruiz et al. 2009). In this communication we evaluate the ecological role that predatory spiders could play in seedling recruitment dynamics if their presence leads to lower arthropod herbivory and higher seedling survival. Previous field research provides little evidence on the ecological effect of spiders on the herbivorous arthropod population (Basset 2001), and therefore we know little about the effects spiders have on seedling recruitment dynamics. This study focuses on several novel ideas that would improve our current understanding of the role of spiders in seedling demography in tropical rainforests. Specifically, we seek to address: (1) whether spider presence correlates negatively with arthropod herbivory and whether arthropod herbivory levels correlate negatively with (2) seedling survival and (3) growth of D. oleifera, a shade-tolerant tropical rainforest tree species. We tested the null hypotheses that seedling performance (survival and growth) is independent of arthropod herbivory and the presence of spiders.

\section{MATERIALS AND METHODS}

Study site: Fieldwork was conducted at the La Unión site located in eastern Nicaragua $\left(12^{\circ} 05^{\prime} \mathrm{N}, 83^{\circ} 55^{\prime} \mathrm{W}\right.$, elevation $\left.10-20 \mathrm{~m}\right)$ from January 2005 to January 2006; mean annual temperature $26^{\circ} \mathrm{C}$ (IRENA 1991). This site is within the lowland tropical rainforest region where we have been conducting research since 1989 (Vandermeer et al. 2000) and is accessible by Caño Negro River. We have worked at the site since 1994. Detailed descriptions of the site were published earlier (Yih et al. 1991, Granzow-de-la-Cerda et al. 1997).

Species in study: D. oleifera, previously known as D. panamensis (Pittier) Record \& Mell (Fournier 2003), is a Neotropical canopy emergent tree common in lowland forests of Central America, Panama and Venezuela. D. oleifera adults can reach a height of about $50 \mathrm{~m}$ and diameter at breast height (DBH) of about $1.5 \mathrm{~m}$ (Clark \& Clark 1992). The wood is very dense and allows saplings to withstand damage inflicted by branches falling from the forest canopy (Clark \& Clark 1991).

Methods: A continuous permanent plot of 6.37 ha was established in 2002 consisting of 10x10 m quadrants. Seedlings were sampled by censusing the entire area. Yearly censuses of the basic demography of each individual of $D$. oleifera have been assessed since the beginning of the study in 2002. The complete seedling survey takes approximately two to three weeks each year. The sample size was 1983 seedlings of D. oleifera from 2005 to 2006 . The effect of arthropods herbivory on seedling survival was measured in 1280 seedlings in 2005 and 703 seedlings in 2006 on a total of 34800 leaflets. Seedlings are considered to be individuals with maximum height $\leq 100 \mathrm{~cm}$ (Clark \& Clark 1984, Clark \& Clark 1985). Maximum height is the vertical distance from the forest floor to the highest green tissue. An aluminum tag with a unique number was looped around the stem of each seedling as these were found. Seedlings were considered dead when the aluminum tags were found alone or when seedlings were completely brown and without green tissue.

Herbivory assessment: For each seedling, a digital photograph of all the leaves and leaflets was made. The percentage of leaf area 
damaged by herbivory was calculated from digital photographs taken from above the seedling canopy in January 2005 and January 2006. Leaflets of $D$. oleifera are remarkably horizontal which allowed us to visually estimate the percentage of herbivory per leaflet from digital photographs. The estimated area lost due to arthropod herbivory of all leaflets was summed and divided by the total number of leaflets in order to assess the percentage of arthropod herbivory per seedling. To determine the accuracy of the estimated arthropod herbivory damage, 100 seedlings were randomly sampled, 50 per year. For those 100 seedlings a second estimate of leaf area lost was conducted using a grid following the methods developed by Dirzo (1987). A $t$ test for two samples was used in order to estimate differences between mean herbivore damage calculated independently from these two herbivory assessment methods. Because there were no significant differences between the methods, the faster visual estimation is reported here.

Spider censuses: Spider species, including different morphs, present on D. oleifera seedlings were collected outside the research plot in 2004, and specimens were deposited at the Natural History Museum of the University of Central America in Managua, Nicaragua. A description of the morphology of each spider was made and when present, the form of web built. Web building spiders were evident because the presence of their webs below or between leaflets and between leaves. The presence or absence of spiders was described in all seedlings present within the research area in January 2005 and January 2006. The field researchers approached each seedling very carefully, trying to minimize the "researcher effect" while examining each seedling for spiders. Two categories for spider location in each seedling of D. oleifera were used: (1) Present, when spiders were spotted on a seedling or when an abandoned spider web was found within or below leaflets of a seedling. In all cases when a spider was present on a seedling only one adult spider was located. It was observed that spiders re-colonized a seedling after spiders either jumped off or dropped down to the ground during the process of measurement. (2) Absent, without a spider and without evidence of spiders. Two categories for spider behavior in seedlings of $D$. oleifera were evaluated. First, when spiders were actively defending a seedling (aggressive behavior). Second, when spiders retreated once researchers approached a seedling (self-defensive behavior).

Herbivory and relation to seedling demography: A one-way ANOVA (Model I) was used to statistically compare the initial means of herbivory damage area in 2005 between the two seedling fate categories, surviving and dead seedlings in 2006 (a factor with two categorical levels). Arthropod herbivory damage was square root transformed in order to normalize data. A one-way ANOVA (Model I) was used to test for differences in mean herbivory damage between seedlings without spiders, seedlings with aggressive spiders and seedlings with self-defensive spiders (less aggressive spiders). Again, arthropod herbivory damage was square root transformed in order to normalize data.

The growth of 514 surviving seedlings, whose height was measured during the two years of the observational study, was evaluated using ANCOVAs. A first model studied the seedling height in the second year $\left(Y_{t}\right)$ as a function of the height in the first year $\left(Y_{t-1}\right)$, the presence/absence of spiders in both years $\left(S_{t}\right.$, $S_{t-1}$ ) and the percentage of arthropod herbivory in both years $\left(H_{t}, H_{t-1}\right)$ :

$$
Y_{t}=\mu+\alpha Y_{t-1}+\beta_{1} S_{t}+\beta_{2} S_{t-1}+\gamma_{1} H_{t}+\gamma_{2} H_{t-1}+\varepsilon
$$

Where $\mu$ is the intercept which gives an idea of the average growth per seedling, $\alpha$ is a parameter relating the current height with the height from the previous year, $\beta_{i}$ accounts for the additional growth due to the presence of spiders in each year, $\gamma_{i}$ measures the effect of herbivory on seedling growth, and $\varepsilon$ is the error which is assumed to be identically and independently distributed. The model presented 
in formula 1 was analyzed in order to test for the statistical significance of each predictor and based on this result the model was simplified by a process of backward elimination (Venables \& Ripley 2002). The predictors in the model that are statistically significant are in Formula 2:

$$
Y_{t}=\mu+\alpha Y_{t-1}+\beta_{1} S_{t}+\beta_{2} S_{t-1}+\gamma_{1} H_{t}+\varepsilon
$$

\section{RESULTS}

Spider census, herbivory and seedling demography: Arthropod herbivory damage in $2005(<20 \%)$ correlated negatively with seedling survival in $2006\left(F_{1,1278}=111.9, \mathrm{p}<0.001\right.$; Fig. 1). There is a tend towards lower arthropod herbivory damage in seedlings with "selfdefensive" spiders and more so in seedlings that harbored spiders with "aggressive" traits $\left(\mathrm{F}_{2,701}=2.65\right.$, $\mathrm{p}<0.05$; Fig. 2).

For seedlings without spiders present and without herbivory, growth was not related to seedling size in the previous year, since the coefficient relating the size in $2006\left(Y_{t}\right)$ to the size in $2005\left(Y_{t-1}\right)$, is almost constant for all these seedlings $(\mu \sim 8 \mathrm{~cm})$ (Table 1,2$)$. For seedlings with spiders present and herbivory damage, growth was positively correlated with spider presence and negatively correlated with arthropod herbivory damage. The result showed that the mean seedling height $(\mu \sim 8$ $\mathrm{cm}$ ), increased approximately $1.5 \mathrm{~cm}$ for each year that a spider was present on the seedlings $\left(\beta_{1}, \beta_{2}\right)$ and decreased $0.75 \mathrm{~cm}$ in height for each percent unit of arthropod herbivory $(\gamma)$. The model presented in formula 2 is also statistically significant ANCOVA $\left(R^{2}=0.72, F_{4,509}=\right.$ $333.5, \mathrm{p}<0.05$; Table 1) and all coefficients are statistically significant (see Table 2).

Figure 3 shows seedling height in 2006 as a function of its value in 2005 with coded symbols that represent the presence of spiders in panel A and for different intensities of arthropod herbivory in panel B. Spider presence correlated with higher growth rates represented by the code " $\mathrm{S}$ " clustered above the 45 degrees line, thus corroborating the correlation between spider presence and seedling growth (Table 1,2; Fig. 3A). In Fig. 3B it is clear that seedling growth correlated negatively with level of arthropod herbivory represented by the green "L" code clustered above the 45 degrees line. A decrease in seedling height is observed in seedlings with high arthropod herbivory, represented by the cluster of blue " $\mathrm{H}$ " codes (Table 1,2). The high degree of scattering suggests that for seedlings without herbivory growth did not depend on seedling height in the previous year - represented by the black " $A$ " code.

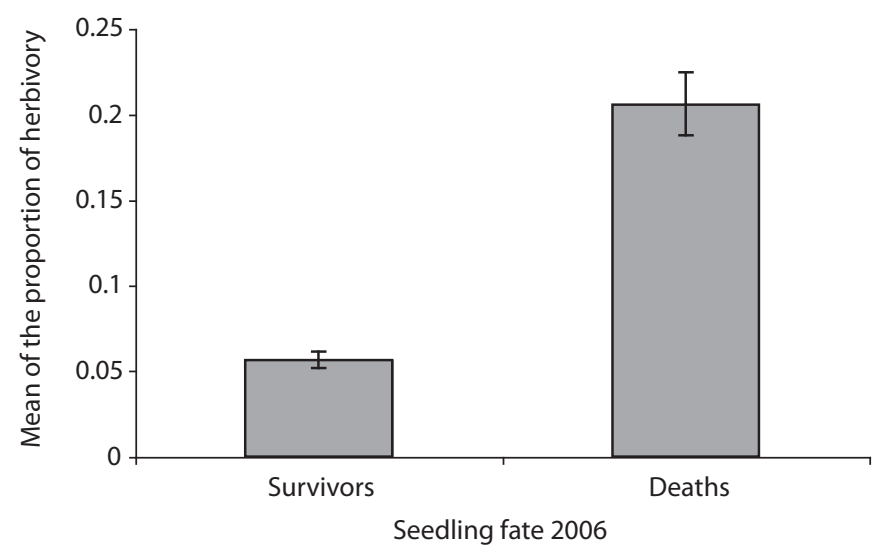

Fig 1. Seedling fate in 2006 as a function of herbivory in 2005. Seedling herbivory was measured in 2005 and the means of this were compared between two seedling conditions (alive or death) in 2006. 


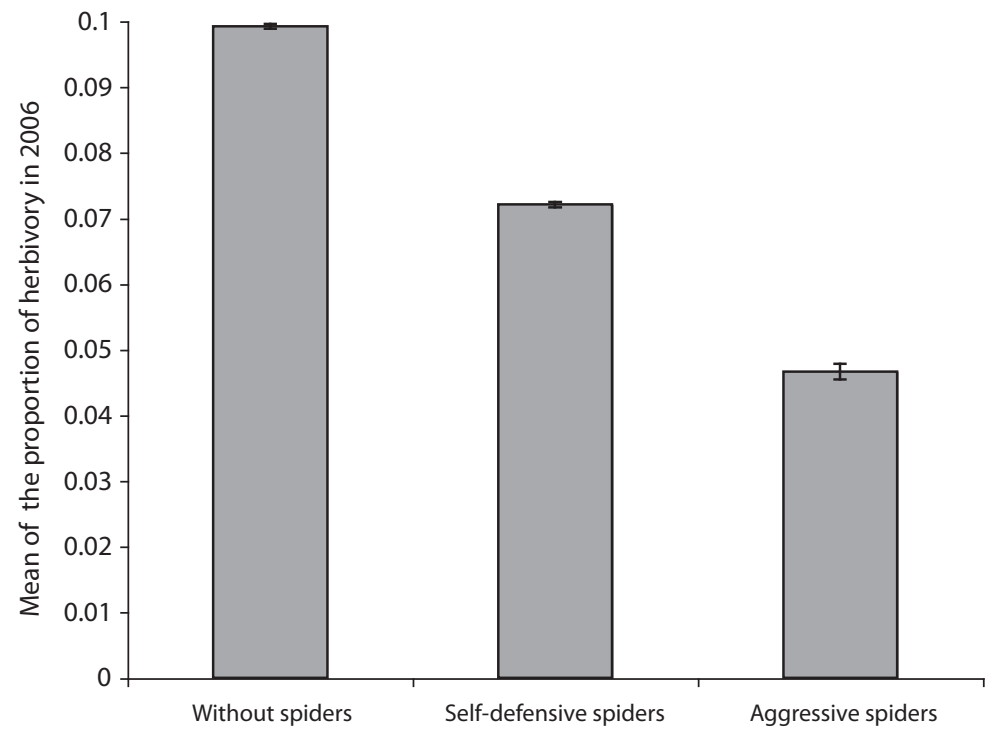

Fig 2. Mean proportion of arthropod herbivory as a function of the behavior of spiders. X-axis corresponds to seedling without spiders (Without), spiders that were less aggressive (self-defensive spiders), and spiders showing a defensive behavior during seedling measurement (aggressive spiders).

TABLE 1

Results of the Analysis of Covariance (ANCOVA) for the model presented in formula 1

$\begin{array}{lcccr}\text { Variable } & \text { D.F. } & \text { Sum Sq } & F \text { value } & \text { p } \\ \text { Height } 05\left(Y_{t-1}\right) & 1 & 35472 & 1098.72 & <2.2 \mathrm{e}-16^{*} \\ \begin{array}{l}\text { Presence of } \\ \text { spiders 06 }\left(S_{t}\right)\end{array} & 1 & 166 & 5.14 & 0.02377^{*} \\ \begin{array}{l}\text { Presence of } \\ \text { spiders 05 }\left(S_{t-1}\right)\end{array} & 1 & 328 & 10.157 & 0.00153^{*} \\ \text { Herbivory 06 }\left(H_{t}\right) & 1 & 1214 & 37.5917 & 1.81 \mathrm{e}-09^{*} \\ \text { Herbivory 05 }\left(H_{t-1}\right) & 1 & 15 & 0.4677 & 0.494377 \\ \text { Error }(\varepsilon) & 485 & 15658 & & \end{array}$

For each variable a code is presented within parenthesis.

* Statistically significant $(\mathrm{p}<0.05)$.

\section{DISCUSSION}

There is a positive indirect effect of spiders on seedling survival and growth since reduced arthropod herbivory correlated with spider presence (Fig. 1). We think that spiders could be preying on or harassing herbivorous arthropods, because field observations suggested that aggressive spider behaviors -within the spider community- led to reduced arthropod herbivory levels. For instance, Fig. 2 shows that aggressive spider behaviors correlated negatively with levels of arthropod herbivory. Although the beneficial effect of the spider community on seedlings could vary in part due to spider species behaviors. The net beneficial 
TABLE 2

Results of the coefficients for the ANCOVA presented in formula 2

$\begin{array}{lcccc}\text { Parameter } & \text { Estimate } & \text { S.E. } & t \text { value } & \text { P } \\ \text { Intercept }(\mu) & 8.127 & 0.90389 & 8.991 & <2 \mathrm{e}-16^{*} \\ \begin{array}{l}\text { Height } 05(\alpha) \\ \text { Presence of } \\ \text { spiders 06 }\left(\beta_{1}\right)\end{array} & 0.832 & 0.02509 & 33.171 & <2 \mathrm{e}-16^{*} \\ \begin{array}{l}\text { Presence of } \\ \text { spiders 05 }\left(\beta_{2}\right)\end{array} & 1.444 & 0.61784 & 2.337 & 0.01983^{*} \\ \text { Herbivory } 06(\gamma) & 1.683 & 0.51823 & 3.247 & 0.00125^{*} \\ & -0.075 & 0.01185 & -6.328 & 5.65 \mathrm{e}-10^{*}\end{array}$

Parameters are coded with a greek symbol and their respective estimate value in the second column. Standard error (S.E.) of the each parameter's estimate, $t$ test value of the estimates and statistical probability (p) for each parameter.

* Statistically significant $(\mathrm{p}<0.05)$.

A

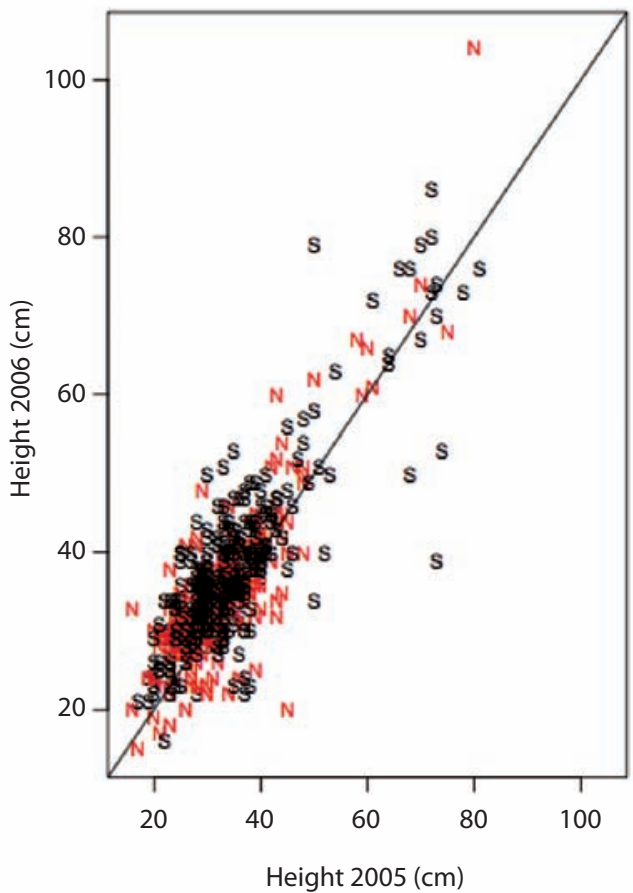

B

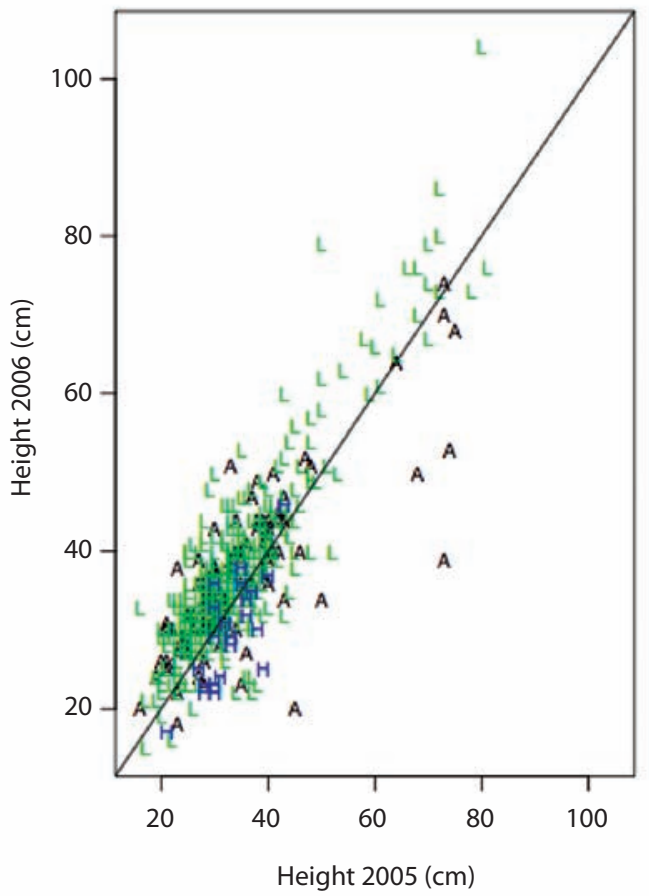

Fig 3. Seedling height in 2006 as function of seedling height in 2005. In panel A seedlings are coded according to the presence of spiders, black with "S" code, or absence of spiders, red "N" code. In Panel B seedlings without arthropod herbivory are presented with black "A" code, while seedlings with intermediate arthropod herbivory level $(<50 \%)$ are represented with green "I" code, and seedlings with high arthropod herbivory levels $(>50 \%)$ are represented with blue "H" code. 
effect of spiders on seedling survival is strongly supported by our findings here (Table 1,2; Fig. $3 \mathrm{~A})$. The biological interaction responsible for the positive indirect effect of spiders on seedlings needs to be investigated in more detail. Future lines of research would focus on identifying the herbivorous arthropods and determining the relative predatory effect of spiders upon herbivorous arthropods of $D$. oleifera.

While spider presence correlated negatively with arthropod herbivory, several spider species could reduce photosynthetic leaf area. For example, in a study of the plant Styrax benzoin in Malaysia, 19\% of seedlings had spiders whose presence led to $2-43 \%$ of reduction in photosynthetic area (Kiew 1982). The reason for this relationship is due to the fact that several spider species roll leaves to use as a refuge. A similar relationship was found in a population of D. oleifera in Costa Rica (Clark \& Clark 1985). In this research spiders are mainly web builders, and these kinds of spiders do not reduced photosynthetic leaf area because web spiders construct webs between leaflets or below leaflets. The relative effect of web builder spiders as predators of herbivorous arthropods might not be as important as spiders in the familiy Salticidae. Web building spiders rely on webs to capture herbivorous arthropods and do not seems to be as aggressive. Spiders in the family Salticidae patrol leaves and hunt herbivorous arthropods and thus could be efficient predators in the D. oleifera system (pers. obs.).

The level of arthropod herbivory decreases with distance to the nearest conspecific adult tree. This result was discussed in great detail in a previous paper (Ruiz et al. 2009). The observed arthropod herbivory pattern suggests that a species-specific arthropod herbivore could be acting upon seedlings of $D$. oleifera . Here, we looked for the herbivorous arthropod responsible of the herbivory damage to seedlings of D. oleifera. Even when we approached seedlings carefully, we were unable to find the herbivorous arthropods on seedlings of $D$. oleifera. Presumably, the damage was done during the night by a nocturnal insect species. Sampling the insect community with sticky traps set up near seedlings of $D$. oleifera would be necessary to identify the agent causing the herbivory damage.

There is a strong pressure of herbivorous arthropods on seedling fate of D. oleifera. It is remarkably that lower levels of herbivory damage $(<20 \%)$ were severe enough to determine seedling growth and fate. This result is nothing new, since the work conducted in a population of $D$. oleifera in a tropical rainforest of Costa Rica showed that even low levels of insect herbivory $(\sim 8 \%)$ were lethal (Clark \& Clark 1985). Low levels of insect herbivory seem to be omnipresent on the forest floor. Even though herbivory decreased with the distance to the nearest conspecific adult tree in both studies, low levels of arthropod herbivory are distributed throughout the forest floor and can be severe enough to lead to seedling mortality in practically all circumstances (Clark \& Clark 1985). This trend has been repeatedly observed in this rainforest in eastern Nicaragua. The interesting question is why such low levels of herbivory damage are so important on seedling demography? One possible answer to this question is the notion that in the shaded forest floor rainforest seedlings may be close to -or at- the compensatory point of light (point where respiration equals photosynthesis). Under these conditions even low levels of herbivory could be subtracting critically necessary photosynthetic tissue for survival.

Seedling height increment was not related to seedling height in the previous year but seedling height is positively related to the presence of spiders and negatively to levels of herbivory. Our previous fieldwork suggested that seedling survival of $D$. oleifera was not related to seedling growth (Ruiz et al. 2009). Perhaps seedling growth may be required only when conditions are suitable - i.e. when a light-gap forms. Thus, maintaining a canopy area above a threshold would keep seedlings close to the compensatory point of light until the occurrence of a light-gap. Under these conditions the beneficial indirect effect of spiders on seedling recruitment matters because spider would lower arthropod herbivore abundance, 
lower arthropod herbivory, and increase seedling survival rate (Fig. 1, 3B).

Although insect herbivory is negatively correlated with seedling height, seedling growth may be determined by other factors. For example, seedling growth of $D$. oleifera in Costa Rica decreased due to apical meristem damage - apparently caused by fungal infections (Clark \& Clark 1985). Another kind of damage that seedlings experienced is the impact of branches and twigs fallings from the canopy (Clark \& Clark 1987); this kind of seedling damage was rare in the D. oleifera population in eastern Nicaragua. In addition, recent field research has suggested beneficial trophic cascade effects of arboreal ants (Floren et al. 2002) and birds (Van Bael et al. 2003) on seedlings because these are predators of herbivorous arthropods. The relative contribution of arboreal ants and birds on seedling growth seem to be minimal in the D. oleifera system because the suspected herbivores are nocturnal and could be safe from ants and birds which in general are diurnal.

In sum, spider presence leads to lower herbivory levels, more seedling growth and better survival of $D$. oleifera. The present study is only correlative and work is still needed to unequivocally establish cause-andeffect relationships among spiders, herbivorous arthropods and seedling demography. In spite of this, the idea that spider presence led to higher seedling recruitment is novel in tropical rainforest studies and opens new and exciting research lines. For example, including trophic cascade effects in forest organization theories would lead us to a better understanding of how recruitment occurs in tropical rainforests.

\section{ACKNOWLEDGMENTS}

Financial support came from a National Science Foundation Research in Undergraduate Institutions grant (DEB-0135350) to Douglas H. Boucher; a block grant from the Department of Ecology and Evolutionary Biology of the University of Michigan (UM) to Javier Ruiz (JR); an individual fellowship from the
International Institute of the UM to JR; an International Foundation for Science Grant, Sweden (D-3939-1) to JR and the Rackham International Student Grant of the University of Michigan to JR. Two undergraduate students from the University of the Autonomous Regions of the Atlantic Coast of Nicaragua (URACCAN) helped with data gathering. Logistical support was provided by members of Proyecto Biodiversidad of URACCAN. Beverly Rathcke, Paul Foster and Sandra Yap gave valuable comments on early versions of the manuscript.

\section{RESUMEN}

Se presenta evidencia que sugiere (1) que los niveles bajos de herbivoría de artrópodos se correlacionan con la supervivencia de plántulas y, (2) que la presencia de arañas se correlaciona con los niveles bajos de herbivoría de artrópodos, crecimiento y supervivencia de plántulas de la especie de bosque húmedo tropical Dipteryx oleifera en el este de Nicaragua. El estudio se realizó entre enero del 2005 y enero del 2006 en una parcela de 6.37 ha establecida en 2002. Se midió altura de plántulas, presencia de arañas en plántulas, comportamiento de arañas, y porcentaje de herbivoría de artrópodos. La suerte de las plántulas fue monitoreada con el objetivo de determinar su correlación con la presencia de arañas, el tamaño inicial de las plántulas y herbivoría de artrópodos. Un GLM mostró que las plántulas con bajo nivel de daño de herbivoría $(<20 \%)$ sobrevivieron más que las plántulas con niveles mayores de daño por herbivoría, las cuales experimentaron mortalidades cercanas al 100 por ciento. Los resultados de otro GLM sugieren que la altura media de plántulas (aprox. 8 $\mathrm{cm}$ ) incrementó aproximadamente $1.5 \mathrm{~cm}$ por cada año en el cual las arañas se encontraron presente en las plántulas, y decrecieron $0.75 \mathrm{~cm}$ en altura por cada unidad de herbivoría. También se reporta menor herbivoría en plántulas colonizadas por arañas de comportamiento agresivo.

Palabras clave: Dipteryx oleifera, herbivoría de artrópodos, demografía de plántulas, Nicaragua.

\section{REFERENCES}

Augspurger, C. \& K. Kitajima. 1992. Experimental studies of seedling recruitment from contrasting seed distribution. Ecology 73: 1270-1284.

Augspurger, C.K. 1983. Seed dispersal of the tropical tree, Platypodium elegans, and the escape of its seedlings from fungal pathogens. J. Ecol. 71: 759-771. 
Augspurger, C.K. 1984. Seedling survival of tropical tree species: interactions of dispersal distance, light-gaps, and pathogens. Ecology 65: 1705-1712.

Basset, Y. 2001. Invertebrates in the canopy of tropical rain forests. How much do we really know? Plant Ecol. 153: 87-107.

Carpenter, S.R., J.J. Cole, J.R. Hodgson, J.F. Kitchell, M.L. Pace, D. Bade, K.L. Cottingham, T.E. Essington, J.N. Houser \& D.E. Schindler. 2001. Trophic cascades, nutrients, and lake productivity: whole-lake experiments. Ecolog. Monog. 71: 163-186.

Clark, D.A. \& D.B. Clark. 1984. Spacing dynamics of a tropical rain forest tree: evaluation of the JanzenConnel model. The American Naturalist 124: 769788 .

Clark, D.A. \& D.B. Clark. 1992. Life history diversity of canopy and emergent trees in a neotropical rain forest. Ecolog. Monog. 62: 315-344.

Clark, D.B. \& D.A. Clark. 1985. Seedling dynamics of a tropical tree: impacts of herbivory and meristem damage. Ecology 66: 1884-1892.

Clark, D.B. \& D.A. Clark. 1987. Population ecology and microhabitat distribution of Dipteryx panamensis a neotropical rain forest tree. Biotropica 19: 236-244.

Clark, D.B. \& D.A. Clark. 1991. The impact of physical damage on canopy tree regeneration in tropical rain forest. J. Ecol. 79: 447-457.

Clark, D.B., D.A. Clark \& P.M. Rich. 1993. Comparative analysis of micohabitat utilization by saplings of nine tree species in neotropical rain forest. Biotropica 25: 395-407.

Coley, P.D. 1983. Intraspecific variation in herbivory on two tropical tree species. Ecology 64: 426-433.

Coley, P.D. 1990. Tasas de herbivorismo en diferentes árboles tropicales, p. 191-199. In E.G. Leigh Jr., A.S. Rand \& D.M. Windsor (eds.). Ecología de un bosque tropical: Ciclos estacionales y cambios a largo plazo. Instituto Smithsonian de Investigaciones Tropicales, Panama City, Panama.

Coley, P.D. \& J. Barone. 1996. Herbivory and plant defenses in tropical forest. Annu. Rev. Ecol. Syst. 27: $305-335$.

Coley, P.D., J.P. Bryant \& F.S.I. Chapin. 1985. Resource availability and plant antiherbivore defense. Science 230: 895-899.
Dirzo, R. 1987. Estudio sobre interacciones planta herbívoros en Los “Tuxtlas" Veracruz. Rev. Biol. Trop. 35: 119-132.

Floren, A., A. Biun \& K.E. Linsenmair. 2002. Arboreal ants as key predators in tropical lowland forest trees. Oecologia 131: 137-144.

Granzow-de-la-Cerda, I., N. Zamora, J.H. Vandermeer \& D.H. Boucher. 1997. Biodiversidad de especies arbóreas en el bosque tropical húmedo del Caribe Nicaragüense siete años después del huracán Juana. Rev. Biol. Trop. 45: 1409-1419.

Gruner, D.S. 2004. Attenuation of top-down and bottom-up forces in a complex terrestrial community. Ecology 85: 3010-3022.

Hairston, N.G., E.S. Frederick \& B.S. Lawerence. 1960. Community structure, population control, and competition. The American Naturalist 94: 421-425.

Hyatt, L.A., M.S. Rosenberg, T.G. Howard, G. Bole, W. Fang, K. Anastacia, K. Brown, R. Grella, K. Hinman, J.P. Kruidiziel \& J. Gurevitch. 2003. The distance dependence prediction of the Janzen-Connell hypothesis: a meta-analysis. Oikos 103: 590-602.

IRENA. 1991. Diagnóstico de los recursos naturales no renovables. In Generalidades sobre la Costa Atlántica. Internal Report (IRENA) Vol II: 9-14.

Kiew, R. 1982. Germination and seedling survival in Kemenyan, Styrax benzoin. Malayasian Forester 45: 69-80.

Levins, R. 1974. Qualitative analysis of partially specified systems. Annals of the New York Academy of Science 231:123-138.

Moreau, G., E.S. Elveleigh, C.J. Lucarotti \& D.T. Quiring. 2006. Ecosystem alteration modifies the relative strength of bottom-up and top-down forces in a herbivore population. J. Animal Ecol. 75:853-861.

Romero, G.Q. \& J. Vasconcellos-Neto. 2004. Beneficial effects of flower-dwelling predators on their host plant. Ecology 85: 446-457.

Ruiz, J., D.H. Boucher, D. Ruiz-Moreno \& Ingram-Flores C. 2009. Recruitment Dynamics of the Tropical Rainforest tree Dipteryx oleifera (Fabaceae) in Eastern Nicaragua. Revista de Biología Tropical 51(1-2): 321-338.

Sullivan, J.J. 2003. Density-dependent shoot-borer herbivory increases the age of first reproduction and 
mortality of neotropical tree saplings. Oecologia 136 96-106.

Van Bael, S.A. \& J.D. Brawn. 2005. The direct and indirect effects of insectivory by birds in two contrasting Neotropical forest. Oecologia 145:658-668.

Van Bael, S. A., J. D. Brawn, and S. K. Robinson. 2003. Birds defend trees from herbivores in neotropical forest canopy. PNAS 100: 8304-8307.

Vandermeer, J.H., I. Granzow-de-la-Cerda, D.H. Boucher, I. Perfecto \& J. Ruiz. 2000. Hurricane disturbance and tropical tree species diversity. Science 290: 788-791.
Venables, W.N. \& B.D. Ripley. 2002. Modern Applied Statistics with S. Springer, New York, USA.

Yih, K., D.H. Boucher, J.H. Vandermeer \& N. Zamora. 1991. Recovery of the rainforest of southeastern Nicaragua after destruction by hurricane Joan. Biotropica 23: 106-113.

\section{INTERNET REFERENCES}

Fournier, L.A. 2003. Dipteryx panamensis (pittier) Record \& Mell. (Downloaded: July 10, 2005, www.rngr.net/ publications/ttsm/folder.2003-07-11.4726). 